http://dx.doi.org/10.1590/0370-44672017710040

\section{Felipe Buboltz Ferreira}

Mestre

Universidade Federal do Rio Grande do Sul - UFRGS Programa de Pós-Graduação em Engenharia de Minas, Metalúrgica e de Materiais - PPGE3M Escola de Engenharia

Porto Alegre - Rio Grande do Sul - Brasil

felipebuboltz@gmail.com

\section{Bruno Deves Flores \\ Mestre \\ Universidade Federal do Rio Grande do Sul - UFRGS Programa de Pós-Graduação em Engenharia de Minas, Metalúrgica e de Materiais - PPGE3M Escola de Engenharia \\ Porto Alegre - Rio Grande do Sul - Brasil bruno.flores@ufrgs.br}

\section{Eduardo Osório}

Professor-Doutor

Universidade Federal do Rio Grande do Sul - UFRGS Programa de Pós-Graduação em Engenharia de Minas, Metalúrgica e de Materiais - PPGE3M Escola de Engenharia

Porto Alegre - Rio Grande do Sul - Brasil eosorio@ufrgs.br

\section{Antônio Cezar Faria Vilela \\ Professor-Doutor \\ Universidade Federal do Rio Grande do Sul - UFRGS Programa de Pós-Graduação em Engenharia de Minas, Metalúrgica e de Materiais - PPGE3M Escola de Engenharia \\ Porto Alegre - Rio Grande do Sul - Brasil vilela@ufrgs.br}

\section{Introduction}

According to a sustainability report posted by Instituto Aço Brasil in 2015, 8\% of coproducts and wastes generated from the steel industry are dust and fines. Among these residues, there is a material called Electric Arc Furnace Dust (EAFD). The production of steel by Electric Arc Furnace (EAF) increased about $12 \%$ in Brazil and $15 \%$ in the world, from 2005 to 2014. Therefore, the amount of EAFD generation has probably increased. According to some authors, the estimation of dust generation per ton of steel produced is around 15-25 kg (Machado, 2004; Alves et al., 2009; Guézennec et al., 2005). The formation of the dust in the steelworks is associated

\title{
Carbothermic reduction of Electric Arc Furnace Dust via thermogravimetry
}

\begin{abstract}
Electric Arc Furnace Dust (EAFD) is a solid waste originated from electric steelmaking furnaces. Currently, according to some authors, there is an estimated generation of 15 to $25 \mathrm{~kg}$ of dust per ton of steel produced. The formation of the dust is related to the following steps of the process: furnace charge, metal volatilization, iron vaporization under the arc, drag of solid particles and, mainly by the collapse of $\mathrm{CO}$ bubbles from metallic bath decarburation. The dust has metals that are harmful to the environment. Otherwise, it is mostly composed of the elements iron, zinc and oxygen. Due to increasing costs for disposal and because it is considered a hazardous waste, industry is looking at the possibility of returning the dust to the steelmaking process. One of the alternatives is by reintroducing the waste in an electric melting shop using self-reducing agglomerates as part of the furnace burden. In this study, self-reducing mixtures are prepared with EAFD and petroleum coke (PET), presenting chemical and physical characterizations. An evaluation about the behavior of the mixtures is carried out in thermobalance, regarding the possibility of use in measuring accurate PET content in self-reducing pellets. As results it could be stated that the elements of economic interest, $\mathrm{Zn}$ and Fe, represent, respectively, 34.23 and $22.80 \%$, in weight. These elements are present in chemical species frankilinite, zincite and magnetite and the reducible oxygen was estimated as $17.90 \%$. Also, it was concluded the optimal content of petroleum coke in the mixtures varies from 10 to $15 \%$, in weight. Therefore, the utilization potential of the thermogravimetric technique in the industrial field for adjustment of carbon content in batches of self-reducing pellets is satisfactory.
\end{abstract}

Keywords: electric arc furnace dust; characterization; thermo-balance.

with the following points: furnace loading; metal volatilization, such as zinc; iron vaporization under the arc or drag of solid particles and mainly, CO bubble collapse, which occurs from decarburization in the metallic bath (Guézennec et al., 2005). The EAFD is mainly composed of Fe and $\mathrm{Zn}$, in different kinds of metallic oxides, like $\mathrm{ZnO}, \mathrm{ZnFe}_{2} \mathrm{O}_{4}, \mathrm{Fe}_{3} \mathrm{O}_{4}$ (Pickles, 2009). For dust with low concentrations of zinc, the major part is present in the form of spinels and ferrites. Thermodynamically, the phase zincite, appears in EAFD when $\mathrm{Zn} /(\mathrm{Fe}+\mathrm{Zn})$ is higher than 0.37 in mass (Buzin, 2009). The higher the $\mathrm{Zn}$ content, the higher the $\mathrm{ZnO}$ content (Machado, 2004). The chemical composition of EAFD depends fundamentally on raw materials, type of steel produced and alloys used (Machado, 2004). It can vary, suffering changes from heat to heat in the same steel plant (Guézennec et al., 2005).

From an environmental point of view, according to (ABNT) NBR 10004-2004, the EAFD is classified as a waste class 1 , hazardous. That is why plants avoid its destination in landfills, and look for alternative methods to disposal through recycling or returning it to the steel production process. These alternatives are based on the metallic content recuperation of the dust (Fe and $\mathrm{Zn}$ ) as well as a search for sustainable 
improvements and costs reductions of the environmental destinations of this waste. In view of steel plants being semi-integrated, there are no reduction reactors, making it difficult to recycle EAFD.

The disposal or treatment of the dust is expensive and is the focus of increased attention in recent years. Some of the EAF dust is being disposed of in hazardous waste landfill sites, but because appropriate storage sites are lacking and placed more distant from the generation point, increasing pressure is being placed on steelmakers to adopt some method for the treatment of the dust (Mantovani and Takano, 2000).

The self-reduction technology consists of an intimate mixture, between the metal oxide, and the carbon material that intends to extract the element of value. The iron oxides and the reductant might be close to each other, in the same compact agglomerate, with a great surface area available for the necessary reduction reactions. This intimate contact is due to the fine granulometry of the constituents (Buzin, 2009; Bagatini, 2011), usually with an auxiliary binder. Decreasing the particle size of the reductant is also responsible for an increased rate of iron oxide reduction at a given temperature. This is due to specific surface increase, which potentiates the Boudouard reaction, due to the fact that the carbon particles have a greater superfice for reaction with $\mathrm{CO}_{2}$ (Nogueira, 2010). In the specific case of EAFD, use of self-reduction agglomerates can make it possible for metallic iron content recycling as well as generating a new dust enriched with zinc content, as the process conditions for this metal tend to accumulate again in EAFD. Dusts with higher zinc content can be more attractive for commercialization as a coproduct.

In view of the increasing interest in EAFD recycling in semi-integrated steel plants, the objective of this paper was divided in the following topics: dust chemical, phases, morphology and physical characterization; Petroleum coke (PET) chemical and physical characterization; Self-reduction of EAFD and PET mixtures, as well as the evaluation of carbothermic reduction behavior of the materials via thermogravimetry.

\section{Materials and methods}

\subsection{EAFD chemical, phases, morphology and physical characterization}

Electric Arc Furnace Dust (EAFD) was collected in a semi-integrated steel plant in the state of Rio Grande do Sul, Brazil. Chemical characterization was conducted via Inductively Coupled Plasma (ICP), X Ray Diffraction (XRD) and Mössbauer spectroscopy. Room Temperature Mössbauer spectra of powder samples was obtained in constant acceleration mode, using a source of 57
Co in $\mathrm{Rh}$ matrix with initial nominal activity of $50 \mathrm{mCi}$. Analysis of the experimental spectra was done by leastsquare fitting assuming Lorentzian line shapes. A high purity $\alpha-F e$ foil was used for velocity-scale calibration. The isomer shift is relative to $\alpha$-Fe. For the XRD, source materials: $\mathrm{Cu} \mathrm{K}$ alpha ; goniometry speed and interval $0.02 \% / 25 \mathrm{~s}-10$ to $70^{\circ} 2$ theta; time 25 s per step and acceleration of $40 \mathrm{kV} / 25 \mathrm{~mA}$.

The carbon content of the dust was determined via dry combustion in an elemental analyzer CNHS.

Physical characterization was also carried out through size particle distribution by laser diffraction, surface area by BET (Brunauer, Emmet and Teller) method, along with Scanning Electron Microscopy (SEM).

\subsection{Petroleum coke (PET) chemical and physical characterization}

PET sample was obtained in the same plant as the EAFD. Due to the coarseness of the sample $(50 \%>0,5 \mathrm{~mm})$,

for the aim of this study (future pellets production), a granulometric adequation was carried out using a ball mill. After material grinding, the PET was characterized using approximate analysis and size particle distribution by laser diffraction.

\subsection{Thermogravimetric EAFD/PET assays}

Thermobalance tests were carried out with mixtures containing EAFD and PET, as follows in Table 1.

\begin{tabular}{c|c|c|c|c|c|c|c} 
Composition & EAFD & 97 & 96 & 95 & 92 & 90 & 95 \\
\hline$(\% \mathrm{wt})$ & PET & 3 & 4 & 5 & 8 & 10 & 15 \\
\hline
\end{tabular}

The tests were conducted in a Netzsch thermobalance, model 409 PC Luxx.

Mixtures, with a mass of $250 \mathrm{mg}$, were introduced into an alumina cylinder crucible

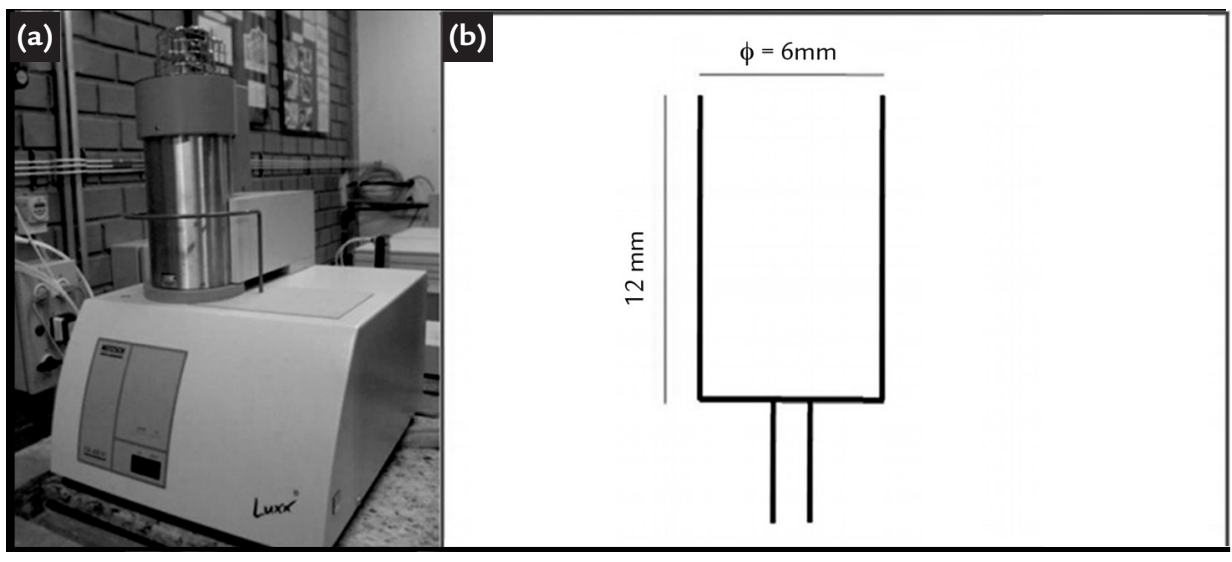

Table 1

Mixtures of dust and

PET for tests in thermobalance.

(37x54mm), being slightly compacted by an instrument for hand manipulation (Figure 1).

Figure 1

a) Thermobalance (LaSid - UFRGS)

and b) Crucible used for the tests. 
The samples were heated in a $30^{\circ} \mathrm{C} / \mathrm{min}$ rate until a temperature of $600{ }^{\circ} \mathrm{C}$, and kept at this temperature for 20 minutes. This first isothermal step aimed to eliminate moisture and a greater part of reductant volatile matter from the samples, avoiding in this way, mass losses due to oxide reduction from the EAFD. After this devolatilization step, the samples were heated at a $30^{\circ} \mathrm{C} / \mathrm{min}$ rate until $1100^{\circ} \mathrm{C}$ and kept at this temperature for 20 minutes. A $100 \mathrm{ml} / \mathrm{min}$ nitrogen flux was introduced in the furnace during the entire experiment.

\section{Results and discussion}

\subsection{EAFD chemical, phases, morphology and physical characterization}

Table 2 shows the elemental composition of the dust, obtained by ICP

Table 2

Chemical composition of EAFD studied.

Elements $\mathrm{Zn}(32.23 \%)$ and $\mathrm{Fe}$ $(22.80 \%)$ represent the majority of the waste. According to literature (Machado, 2004), zinc concentration in dusts originated in steelmaking may vary between 11.12 and $26.90 \%$. The reason for a more elevated content herein could be associated with greater utilization of galvanized

Figure 2 $\mathrm{X}$ Ray Diffractogram of the dust sample.

The analysis indicates, mainly, the presence of franklinite $\left(\mathrm{ZnFe}_{2} \mathrm{O}_{4}\right)$, zincite $(\mathrm{ZnO})$ and magnetite $\left(\mathrm{F}_{3} \mathrm{O}_{4}\right)$. These mineralogical phases match with what was expected in a typi-

Table 3

Quantification of ferrous phases in the EAFD via Mössbauer spectroscopy.

It was verified that the iron present in the dust $(22.8 \%$ - Table 2$)$ was found in franklinite $(75 \%)$ and magnetite $(25 \%)$ mineral. Nevertheless, another technique was conducted:

and dry combustion in an elemental analyzer CNHS.

\begin{tabular}{c|c|c|c|c|c|c|c}
\multirow{2}{*}{$\begin{array}{c}\text { Elemental } \\
\text { Composition of } \\
\text { the Dust } \\
(\% \mathrm{wt})\end{array}$} & $\mathrm{Zn}$ & $\mathrm{Fe}$ & $\mathrm{Mn}$ & $\mathrm{Ca}$ & $\mathrm{Mg}$ & $\mathrm{Pb}$ & $\mathrm{Na}$ \\
\cline { 2 - 8 } & 34.23 & 22.8 & 2.75 & 2.49 & 1.76 & 1.10 & 1.00 \\
\cline { 2 - 8 } & $\mathrm{K}$ & $\mathrm{AL}$ & $\mathrm{Cu}$ & $\mathrm{Ba}$ & $\mathrm{Cd}$ & $\mathrm{Ni}$ & $\mathrm{C}$ \\
\cline { 2 - 8 } & 0.97 & 0.20 & 0.15 & 0.05 & 0.03 & 0.01 & 0.91 \\
\hline
\end{tabular}

scrap in the production of the steel in the plant where the EAFD was sampled. The carbon content of EAFD is $0.91 \%$. Other elements shown in Table 2 are inside the usual ranges found in literature (Machado, 2004; Nyrienda, 1991). Non-analyzed elements, among them oxygen, complete the characterization of the EAFD and total

\section{$31.53 \%$ of the EAFD.}

Phase composition determination was conducted by X Ray Diffraction (SIEMENS-Bruker-AXS D500, with a $\mathrm{Cu}$ tube equipment, in $40 \mathrm{kV} / 25 \mathrm{~mA}$ ). The XRD diffractogram, in Figure 2, shows the crystalline species identified in EAFD.

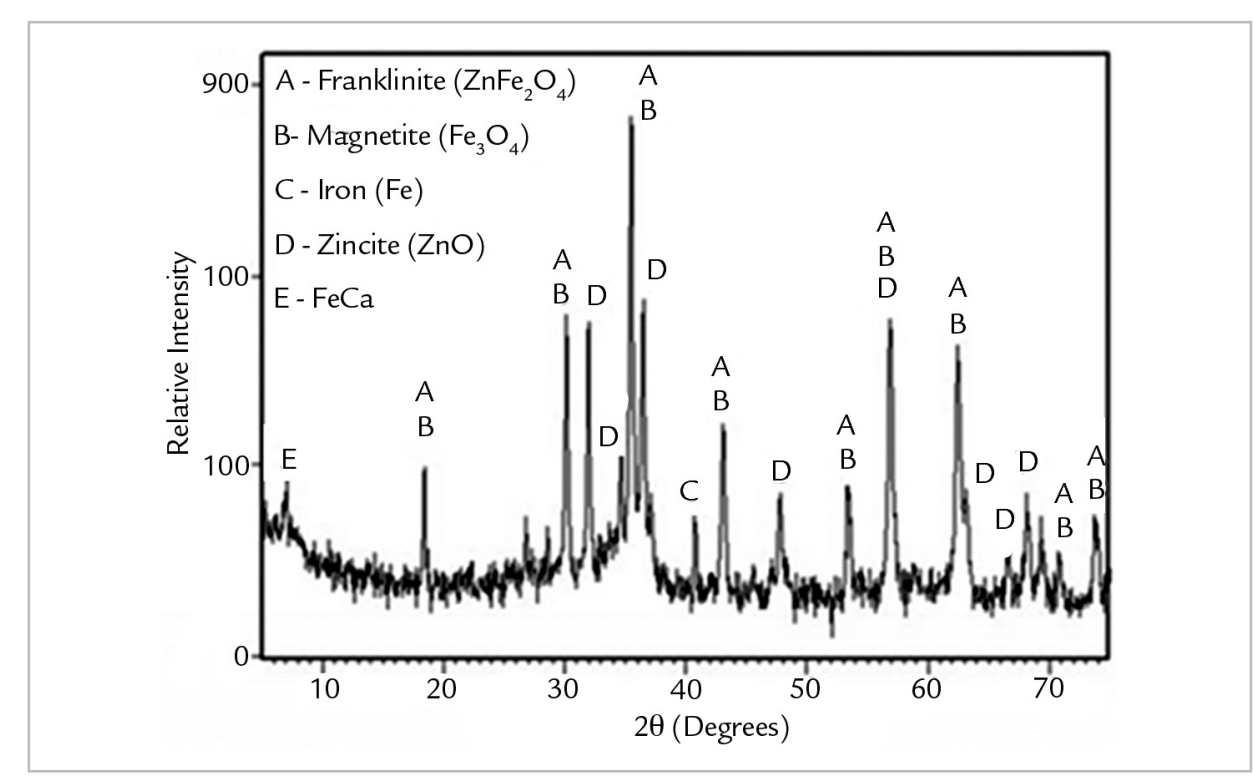

cal EAFD composition from the literature. According to several authors (Machado, 2004; Silva et al., 2008; Telles et al. 2010), the result for this characterization technique was very similar.

In order to support ferrous phase characterization, a Mössbauer spectroscopy analysis was carried out and the results are in Table 3 .

\begin{tabular}{c|c|c} 
Iron phases distribution & $\mathrm{Zn} \mathrm{Fe}_{2} \mathrm{O}_{4}$ & $\mathrm{Fe}_{3} \mathrm{O}_{4}$ \\
\hline$(\% \mathrm{wt})$ & 75 & 25 \\
\hline
\end{tabular}

Mössbauer spectroscopy, as a complementary analysis to XRD, because of its quantitative factor.

From the elemental composition of EAFD indicated in Table 2 and the ferrous phases quantified in Table 3, the majority of oxide phase content present in the waste can be estimated $(\mathrm{ZnO}$, $\mathrm{ZnFe}_{2} \mathrm{O}_{4}, \mathrm{Fe}_{3} \mathrm{O}_{4}$ ) (Table 4). 


\begin{tabular}{c|c|c|c|c} 
EAFD Composition & $\mathrm{ZnFe}_{2} \mathrm{O}_{4}$ & $\mathrm{ZnO}$ & $\mathrm{Fe}_{3} \mathrm{O}_{4}$ & Other phases \\
\hline$(\% \mathrm{wt})$ & 36.9 & 30.2 & 7.9 & 25.1 \\
\hline
\end{tabular}

This estimation was conducted according to a procedure described by Machado et al (2006).

Franklinite $(36.8 \%)$, zincite $(30.2 \%)$ and magnetite $(7.9 \%)$ represent the major- ity of compounds found within the EAFD. According to Takano et al (1999), the zincite content was higher in dusts rich in zinc; as much zinc is identified in the waste, more zincite will appear in the char-
Table 4

Estimation on majority phases of the dust.

acterization. Other compounds without $\mathrm{Zn}$ and $\mathrm{Fe}$ presence totaled $25.1 \%$. Using the estimation in Table 4, we calculated the reducible oxygen content associated to all those phases according to Equation 1:

$$
O_{\text {reducible }}=\% \mathrm{ZnFe}_{2} \mathrm{O}_{4} \cdot \frac{M_{\mathrm{O}}}{M_{\mathrm{ZnFe}_{2} \mathrm{O}_{4}}}+\% \mathrm{ZnO} \cdot \frac{M_{\mathrm{O}}}{M_{\mathrm{ZnO}}}+\% \mathrm{Fe}_{3} \mathrm{O}_{4} \frac{M_{O}}{M_{\mathrm{Fe}_{3} \mathrm{O}_{4}}}
$$

Where, the reducible oxygen corresponds to the sum of the oxygen weight percentage of each phase shown above $\left(\mathrm{ZnFe}_{2} \mathrm{O}_{4}, \mathrm{ZnO}\right.$ and $\left.\mathrm{Fe}_{3} \mathrm{O}_{4}\right)$. Thereby, the reducible oxygen in the
EAFD, content is $17.9 \%$. With this number, it was possible to measure the minimal carbon content necessary for consumption of this percentage of oxygen, in mass.

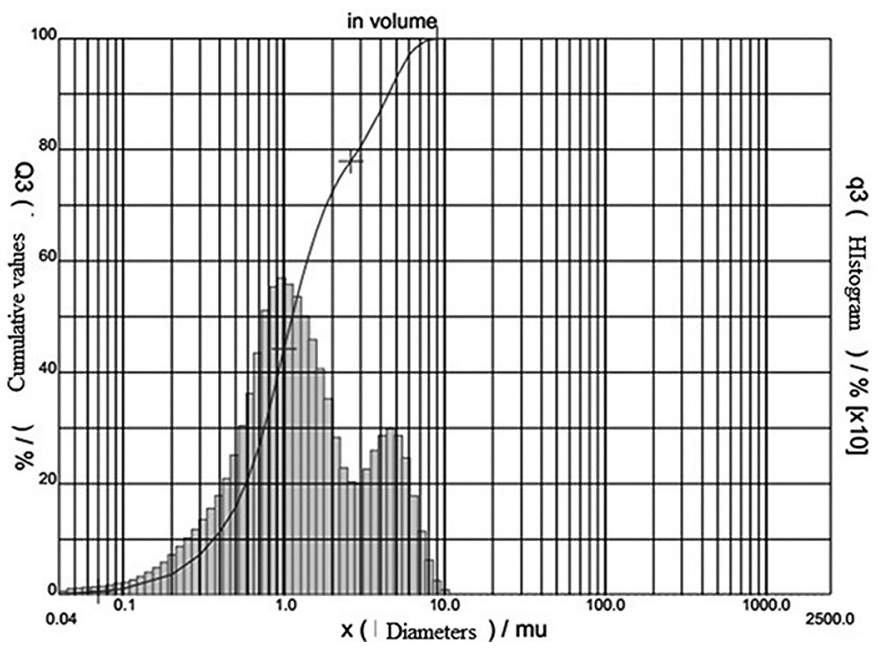

In terms of granulometry, over $80 \%$ of the particles of EAFD, have a size of less than $5 \mu \mathrm{m}$.

The bubble burst at the surface of the steel bath is responsible for the shape formation of an upward liquid jet from which
The surface area (BET) was 3.93 $\mathrm{m}^{2} / \mathrm{g}$, a value found to be consistent with the range described in literature

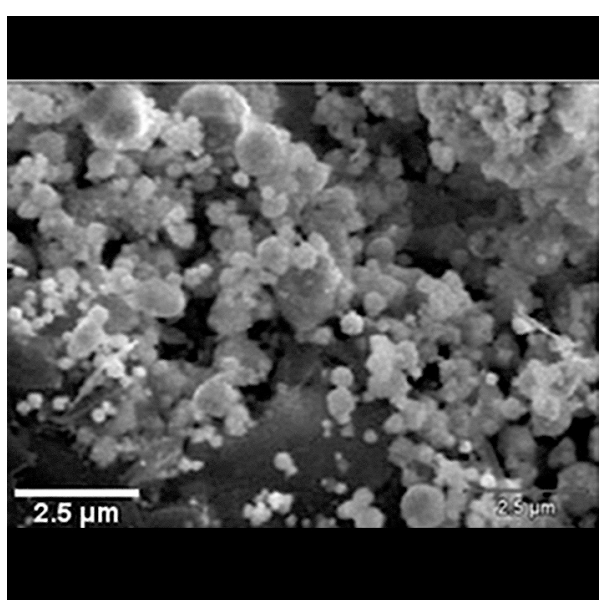

some visible droplets can be ejected and give the spherical shape. The SEM analysis was conducted in order to compare the
Particle size distribution was conducted by laser diffraction size analysis to determine granulometric characterization (Figure 3).
Figure 3

Granulometric distribution of the EAFD.

(Nyrienda, 1991).

The spherical shape of the EAFD is shown in Figure 4, an image taken by SEM.

Figure 4

SEM image of the dust.

sample used in this study in terms of particle shapes to a typical EAFD also found in literature (Mantovani et al., 2002). 


\subsection{Petroleum coke chemical and physical characterization}

PET composition is shown in Table 5.

Table 5

PET Approximate analysis.

The reductant has a low content of inorganic contaminants $(0.6 \%)$ and a high content of fixed carbon. Utiliza-

Figure 5

Granulometric distribution of the PET.

The PET was grinded to a level

\begin{tabular}{c|c|c|c} 
& Fixed Carbon & Volatile Matter & Ashes \\
\hline$(\% \mathrm{wt})$ & 89.4 & 10.0 & 0.6 \\
\hline
\end{tabular}

tion of a carbon source with a low ash content could be attractive for use in furnaces, as the generation of slag might be reduced.

Figure 5 shows the granulometric distribution of the PET.

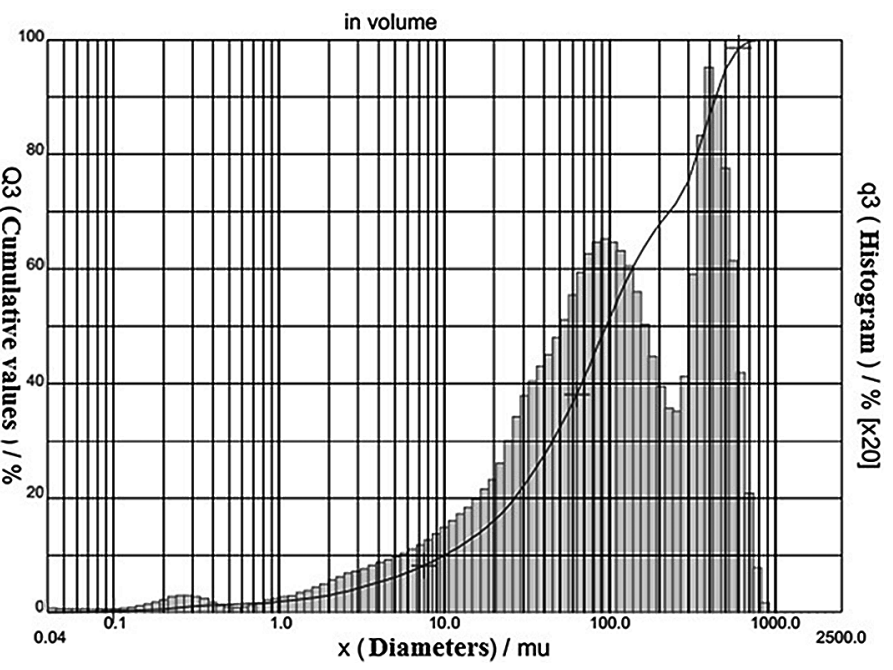

where $50 \%$ of its particles were below $100 \mu \mathrm{m}$ in diameter.

\subsection{Thermogravimetric EAFD/PET assays}

During the first step of the weight losses observed (until $600^{\circ} \mathrm{C}$ ), the curves

Figure 6

Thermogravimetric assays for the mixtures of dust and PET.

With heating, it was observed that the samples showed a sharp weight loss (Figure 6), which begins in temperatures close to $900{ }^{\circ} \mathrm{C}$ and goes on until the maximum

are related to moisture evaporation from raw materials, as well as partial PET de-

volatization (Figure 6).

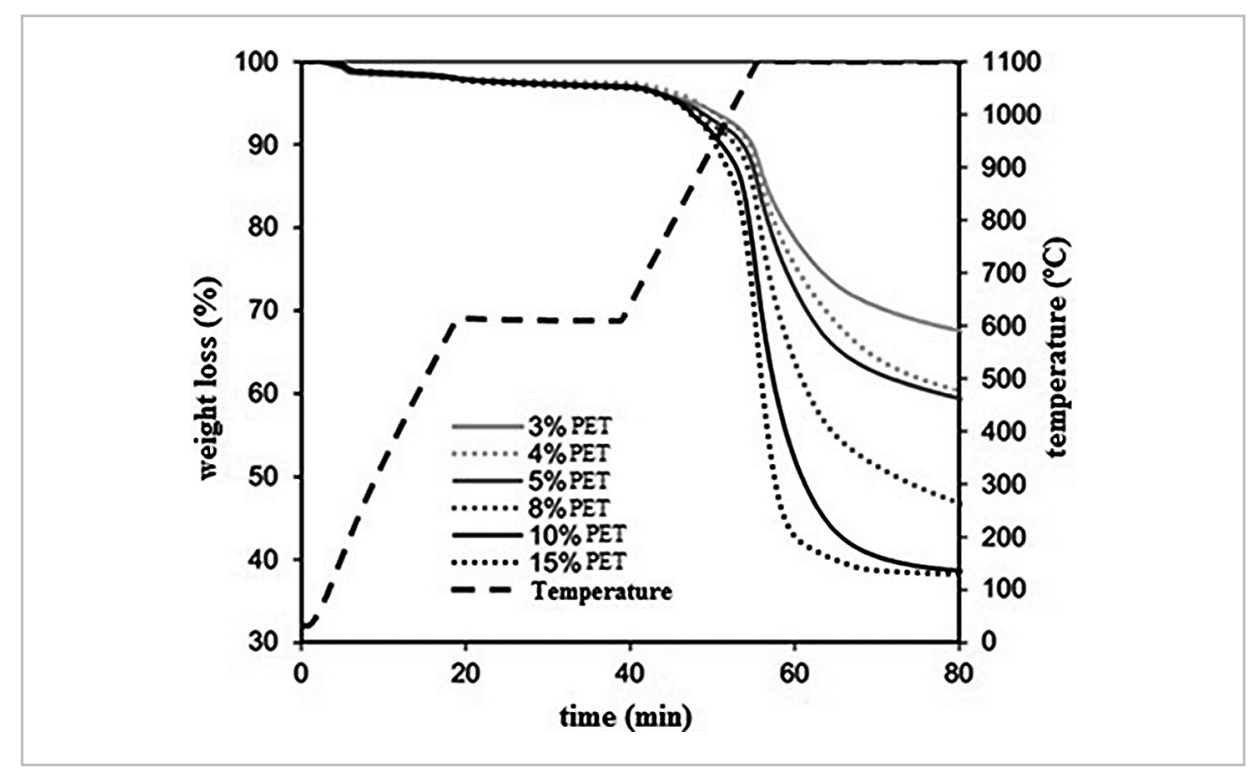

temperature of the test $\left(1100{ }^{\circ} \mathrm{C}\right)$. The behavior of the samples in temperatures above $900^{\circ} \mathrm{C}$ was related to the reduction of metallic oxides containing reducible oxygen - reactions (2) and (3) -, gasification of fixed carbon (4) in petroleum coke and mainly because of zinc expelled out the system in the gas form (3). 


$$
\begin{gathered}
\mathrm{Fe}_{x} \mathrm{O}_{y(\mathrm{~s})}+\mathrm{CO}_{(\mathrm{g})}=\mathrm{Fe}_{x} \mathrm{O}_{y-1(\mathrm{~s})}+\mathrm{CO}_{2(\mathrm{~g})} \\
\mathrm{ZnO}_{(\mathrm{s})}+\mathrm{CO}_{(\mathrm{g})}=\mathrm{Zn}_{(\mathrm{g})}+\mathrm{CO}_{2(\mathrm{~g})} \\
\mathrm{C}_{(\mathrm{s})}+\mathrm{CO}_{2(\mathrm{~g})}=2 \mathrm{CO}_{(\mathrm{g})}
\end{gathered}
$$

Mixtures of 10 and $15 \%$ PET were verified to have similar weight losses. The weight loss due to zinc volatilization was caused by reduction/ vaporization of this metal, since after reduction, the metallic zinc is immedi-

\begin{tabular}{|c|c|c|c|c|c|c|c|}
\hline \multicolumn{2}{|c|}{ Mixtures } & \multicolumn{4}{|c|}{ Constituints ( $\%$ in weight) } & \multirow{2}{*}{$\begin{array}{c}\text { Maximum } \\
\text { estimated } \\
\text { weight } \\
\text { loss }\end{array}$} & \multirow{2}{*}{$\begin{array}{c}\text { Total loss } \\
\text { in the test } \\
(\%)\end{array}$} \\
\hline EAFD & PET & $\mathrm{O}_{\text {reducible }}$ & $\mathrm{Zn}$ & (Cfixed + C EAFD) & ble & & \\
\hline 97 & 3 & 17.4 & 33. & 3.6 & 0.20 & 54.2 & 31.7 \\
\hline 96 & 4 & 17.2 & 32.9 & 4.4 & 0.26 & 54.5 & 39.6 \\
\hline 95 & 5 & 17.0 & 32.5 & 5.3 & 0.31 & 54.8 & 40.5 \\
\hline 92 & 8 & 16.5 & 31.5 & 8.0 & 0.48 & 56.0 & 53.5 \\
\hline 90 & 10 & 16.1 & 30.8 & 9.8 & 0.61 & 56.7 & 59.2 \\
\hline 85 & 15 & 15.2 & 29.1 & 14.2 & 0.93 & 58.5 & 59.0 \\
\hline
\end{tabular}
ately vaporized $\left(907^{\circ} \mathrm{C}\right.$ ) (Rosenqvist, 1973).
The maximum estimated weight loss calculated is the sum of reducible oxygen, zinc and carbon content. It is

This equation establishes a mass carbon/oxygen ratio equal to 0.75 for total reduction of iron and zinc oxides present in EAFD. Thus, the behavior of weight loss of the different samples in Table 6 could be explained by evaluating the $\mathrm{C} / \mathrm{O}_{\text {reducible }}$ ratio of each mixture. The weight loss increases as this ratio gets close to 0.75 . However, it was verified that mixtures of 10 and $15 \%$ PET had similar weight losses. Thus, for mixtures with smaller $\mathrm{C} / \mathrm{O}_{\text {reducible }}$ ratios, the carbon percentage was not enough to achieve the total reduction of iron and zinc oxides. Therefore, the verified weight loss of 3 to $8 \%$ of the petroleum coke, is inferior to the estimated maximum weight loss. On the other hand, for mixtures with 10 and $15 \%$, the verified PET losses are close to the estimated maximum weight loss (Table 6). In the same way the difference between the total loss of the test regarding the $\mathrm{C} / \mathrm{O}_{\text {reducible }}$ ratio could be explained.

The weight loss compared to the

\section{Conclusions}

Taking into consideration the self-reducing mixtures behavior in thermogravimetric tests, it could be concluded that:

As expected, elements of eco- remarkable that it does not consider moisture, volatile matter and volatile elements like lead and cadmium.

$$
\mathrm{MO}_{(\mathrm{s})}+\mathrm{C}_{(\mathrm{s})}=\mathrm{M}_{(\mathrm{s})}+\mathrm{CO}_{(\mathrm{g})}
$$

estimated maximum weight loss for the sample with $10 \%$ PET indicates, possibly, the total reduction of iron and zinc oxides present in EAFD, even with a $\mathrm{C} / \mathrm{O}_{\text {reducible }}$ inferior to 0.75 . This could be due to mixed $\mathrm{CO} / \mathrm{CO}_{2}$ formation, i.e., with lower carbon consumption than reaction (5) predicts.

While the iron and zinc oxide reduction reactions occurs together, the slowest step controls the global process of the agglomerate reduction. According to several studies (Carvalho et al., 1994; Fruehan, 1977; Moon and Sahajwalla, 2006, Bagatini et al., 2011), the reduction kinetics of self-reducing agglomerates, mainly in low temperatures, is controlled by the Boudouard reaction. It could be observed in Figure 6 for temperatures from 900 to $1000^{\circ} \mathrm{C}$, when this reaction starts. In this range of temperature, with the use of petroleum coke, the Boudouard reaction occurs, according to Bagatini et al., 2011. After this, the reduction of the nomical interests, such as iron and zinc, represent 22.80 and $34.23 \%$, respectively of the EAFD sampled. These elements are present in chemi-
Mixtures compositions, the estimated and total weight loss in thermogravimetric tests, can be seen in Table (6).

Table 6

Mixtures compositions, the maximum estimated and total weight loss in thermogravimetric tests.

Carbothermic reduction of iron oxides and zinc in the EAFD could be represented generically by equation (5).

iron and zinc oxides takes place, including the volatilization of $\mathrm{Zn}$. It could be concluded that if there is enough carbon and sufficient energy, the overall reduction reaction of iron oxides will not be affected by the presence of zinc oxide.

Furthermore, from the point of view of practical application, the study carried out can be used as a methodology to determine the optimal carbon content in formulations of this kind of experiment. Therefore, according to Figure 6, economy in usage of reductant or reaction kinetics can be taken into account, for the case where weight losses are close, for example in mixtures of 10 and $15 \%$ PET. In this case there is the option to use percentages below $15 \%$ of reductant agent. Greater contents of PET lead to higher consumption of raw material, but this percentage has a more favorable kinetic value, which could be advantageous, for instance, in EAF operations with a focus on the reintroduction of pellets. cal species $\mathrm{ZnFe}_{2} \mathrm{O}_{4}(36.9 \%), \mathrm{ZnO}$ $(30.2 \%)$ and $\mathrm{Fe}_{3} \mathrm{O}_{4}(7.9 \%)$. From this content, the EAFD reducible oxygen was estimated as $17.9 \%$. 
Throughout carbothermic tests via thermogravimetry, it was stated that the optimal content of petroleum coke $($ fixed carbon $=89.4 \%$; ashes $=0.6 \%$ ) used in the mixtures varies from 10 to $15 \%$, in weight. It was verified that the oxide reduction occurs from $900^{\circ} \mathrm{C}$, which is linked to the effective beginning of the petroleum coke gasification reaction.

Considering the way of determining the optimal content of reductant and the temperature used, it could be stated that the utility potential of this assay is satisfactory in the industrial field is as a support for the production of self-reducing pellets that could be used in meltshops for steel production.

\section{Acknowledgments}

The authors would like to thank CAPES and Gerdau, for the financial support.

\section{References}

INSTITUTO AÇO BRASIL. Relatório de Sustentabilidade 2015. Rio de Janeiro, 2015. WORLD STEEL ASSOCIATION. Steel Statistical Yearbook 2014. Brussels: World Steel Association.

ASSOCIAÇÃO BRASILEIRA DE NORMAS TÉCNICAS. NBR 10004: resíduos sólidos classificação. Rio de Janeiro, 2004.

ALVES, J. O., ESPINOSA, D. C. R., TENÓRIO, J. A. S. Recycling of steelmaking slag aiming at the production of thermos-acoustic insulation. In: ANNUAL MEETING AND EXIBITION, 38. Anais... São Francisco: TMS, 2009, p. 921.

BAGATINI, M. C. Estudo da reciclagem da carepa através de briquetes autorredutores para uso em forno elétrico a arco. Porto Alegre: Universidade Federal do Rio Grande do Sul, 2011. (Tese de Doutorado).

BAGATINI, M. C., ZYMLA, V., OSÓRIO, E., VILELA, A. C. F. Characterization and reduction behavior of mill scale. ISIJ International. v. 51, p. 1072-1079, 2011.

BUZIN, P. J. W. K., HECK N. C., VILELA A. C. F. EAFD - a thermodynamic analysis and classification of dust types. In: SEMINÁRIO DE ACIARIA - INTERNACIONAL, 45. Anais... Porto Alegre: ABM - Associação Brasileira de Metalurgia, Materiais e Mineração, 2014, p. 10.

BUZIN, P. J. W. K. Desenvolvimento de briquetes autorredutores a partir de carepas de processamento siderúrgico para utilização em forno elétrico à arco. Porto Alegre: Universidade Federal do Rio Grande do Sul, 2009. (Dissertação de Mestrado).

CARVALHO, R. J, NETO, P. G. Q., D'ABREU, J. C. Kinetics of reduction of composite pellets containing iron ore and carbon. Canadian Metallurgical Quarterly, v. 33, n. 3, p. 217-225, 1994.

FRUEHAN, R. J. Rate of reduction of iron oxides by carbon. Metallurgical Transactions B, v. 8, p. 279-286, 1977.

GUÉZENNEC, A. G., HUBER, J. C., PATISSON, F., SESSIEC, P., BIRAT, J. P., ABLITZER, D. Dust formation in electric arc furnace: birth of particles. Powder Technology, v. 157, n. 1-3, 2005.

MACHADO, J. G. M. S. Estudo da caracterização e avaliação da influência do tempo na redução carbotérmica do pó de aciaria elétrica. Porto Alegre: Universidade Federal do Rio Grande do Sul, 2009. (Dissertação de Mestrado, 2004).

MACHADO, J. G. M. S., BREHM F. A., MORAES, C. A. M., SANTOS, C. A., VILELA, A. C. F. Characterization study of electric arc furnace dust phases. $\mathrm{Ma}$ terials Research. v. 9, n. 1, p. 42, 44, 2006.

MANTOVANI, M. C., TAKANO, C. The strength and the high temperature behaviors of self-reducing pellets containing EAF dust. ISIJ International. v. 400, n. 3, p. 224-230, 2000.

MANTOVANI, M. C., TAKANO, C., BÜCHLER, P. M. Electric arc furnace dust-coal composite pellet: effects of pellet size, dust composition, and additives on swelling and zinc removal. Ironmaking and Steelmaking. v. 29, n. 3, p. 257-265, 2002.

MOON, J., SAHAJWALLA, V. Investigation into the role of the Boudouard reaction in self-reducing iron oxide and carbon briquettes. Metallurgical and Materials Transactions B. v. 37, p. 215-221, 2006.

NOGUEIRA, A. E. A. Estudo da redução carbotérmica de minérios de ferro na forma de pelotas ou misturas autorredutoras em forno rotativo. São Paulo: Universidade de São Paulo, 2010. (Tese de Doutorado).

NYRIENDA, R. L. The processing of steelmaking flue dust: a review. Minerals 
Engineering. v. 4, n. 7-11, p. 1003-1025, 1991.

PICKLES, C. A. Thermodynamic modelling of the multiphase pyrometallurgical processing of electric arc furnace. Minerals Engineering. v. 22, n. 11, p. 977-985, 2009.

PICKLES, C. A. Thermodynamic modelling of the formation of zinc-manganese ferrite spinel in electric arc furnace dust. Journal of Hazardous Materials. v. 179, n. 1-3, p. 309-317, 2010.

SILVA M. C., BERNARDES A. M., BERGMANN, C. P., TENÓRIO, J. A. S., ESPINOSA, D. C. R. Characterization of electric arc furnace dust generated during plain carbon steel production. Ironmaking and Steelmaking. v. 35, n. 4, p. 315320, 2008

ROSENQVIST, T. Principles of extractive Metallurgy. Nova York: McGraw-Hill, 1974.

TAKANO, C., CAVALAMNTE, F. L., MANTOVANI, M. C., MOURÃO, M. B. Electric arc furnace dust characterization and recycling by self-reducing pellets. In: JAPAN-BRAZIL SYMPOSIUM ON DUST PROCESSING. Anais... São Paulo, 1999, p. 37-48.

TELLES, V. B., OLIVEIRA, J. R., ESPINOSA, D. C. R., TENÓRIO, J. A. S. Reaproveitamento da poeira de aciaria elétrica através do processo de micropelotização. In: SEMINÁRIO DE ACIARIA INTERNACIONAL. 2010, Anais... Resende, 2010, p. 41.

Received: 13 March 2017 - Accepted: 20 February 2018. 